\title{
Quality of Service and Price Perception Affect Customer Loyalty With Consumer Satisfaction As a Mediation Variables
}

Margareta Evy da Silva ${ }^{1}$

${ }^{1}$ Dili Institue of Technology, Dili, Timor Leste

\begin{tabular}{|c|c|}
\hline ARTICLE INFO & ABSTRACT \\
\hline $\begin{array}{l}\text { Received November } 2020 \\
\text { Accepted November } 2020 \\
\text { Published December } 2020\end{array}$ & $\begin{array}{l}\text { This study investigates the effect of service quality and perceived } \\
\text { price on customer satisfaction and the effect of customer } \\
\text { satisfaction on customer loyalty. This study also seeks to }\end{array}$ \\
\hline $\begin{array}{lr}\text { Keywords: } & \text { Customer } \\
\text { Loyalty, } \quad \text { Consumer } \\
\text { Satisfaction, Service Quality, } \\
\text { Price Perspective }\end{array}$ & $\begin{array}{l}\text { determine the mediating role of customer satisfaction on the } \\
\text { relationship between service quality and price perceptions and } \\
\text { customer loyalty. This study focuses on observations on } 100 \\
\text { students in Sidoarjo who have made purchases at Indomaret- } \\
\text { Sidoarjo. The research hypothesis testing adopted the Structural } \\
\text { Equation Model-Partial Least Square (SEM-PLS) technique using } \\
\text { SmartPLS. This study found that customer satisfaction has a } \\
\text { significant effect on customer loyalty and perceived price also has } \\
\text { a significant effect on customer loyalty. However, this research } \\
\text { proves that service quality does not have a significant effect on } \\
\text { customer satisfaction. }\end{array}$ \\
\hline
\end{tabular}

\section{Introduction}

Nowadays, the development of the retail business in Indonesia shows a truly positive popularity, this can be seen from the increasing number of minimarkets markets every year. The strong competition in the retail industry requires that the domestic retail business be managed professionally and can serve consumers [1]. So that the service strategy to attract consumers by observing pricing policies, and customer satisfaction [2]. This requires a pricing strategy and customer satisfaction to enable consumer loyalty in the retail business being run [3].

Customer loyalty is usually referred to as a person's loyalty to a product, a service, and a company. Customer loyalty is the expression and continuity of customer satisfaction by implementing the services offered by the company, and customers who are loyal to the company.

Consumer loyalty can have a significant impact on the company's business development, this can occur because the costs involved in attracting consumers are higher than the rates for maintaining loyal customers [4]. The loss of consumers will lead to company collapse. Therefore, businesspeople need to retain consumers by increasing loyalty [5].

The influence between service quality and customer loyalty and satisfaction as a mediating variable has been observed by experts [6]. As the survey results show, service quality has a positive impact on customer satisfaction. The population used for the study 
is the population of all consumers who have purchased at Indomart Jenggala 2 Gedangan. While the technique used in sampling used in this study is objective sampling. The data analysis technique uses SmartPLS version 3. The level of loyalty can be influenced by several aspects, namely, customer satisfaction, service quality, and price perception.

This customer loyalty can be influenced by customer satisfaction [7]. Satisfaction is based on feelings of disappointment or pleasure felt by someone by comparing product performance (results) with desired performance (results) [8]. All companies need to maintain their position in the market to remain competitive and keep their customers satisfied with better service [9].

In addition to customer satisfaction, there are other things that can affect customer loyalty, namely service quality [4]. Service quality is an important factor for a company in focusing on achieving customer loyaltyp [6]. Experts describe service quality as a dynamic situation and relate to service products, humanity, progress, and an environment in which consumers can meet and exceed consumer needs. Service quality is the key to a company's success, especially in the retail industry [2]. With such a statement, service quality must be a major focus in the company's attention. This statement is based on the results of a survey conducted by experts that the quality of service is said to be good if it has a positive impact on customer loyalty in minimarkets [8].

Price is the value for money intended to get the mix of products and services that come with it [9]. Perception based on experts is the progress of individuals in selecting, arranging, and translating stimuli (stimuli) into a comprehensive illustration. Although the fixing of the value for money is considered as some determining factor for some companies, the pricing strategy is not the only method used to solve different problems for a company, but each company must make decisions about pricing issues appropriately [10]. One of the company's methods to achieve customer loyalty is to offer consumers fair and reasonable prices [11]. Cheap or expensive products are relative. Researchers have found that there is a positive effect between price and customer loyalty [12].

Indomart is a trading company or retail business that aims to build the best retail distribution network in Indonesia that is owned by a broad community. However, Indomart's top brand data in the last 3 years is always below Alfamart.

Sidoarjo is an area that has tight competition in the retail business sector such as minimarkets. Meanwhile, Indomaret is a minimarket that competes with other minimarkets in Sidoarjo. One of Indomaret's address is Jl. Jenggala No.22, Megersari, Gedangan, Kec. Gedangan, Sidoarjo Regency, East Java. Indomaret Jenggala 2 has advantages over other Indomaret such as complete products, ample parking space and a large area for resting in the front. Based on this, the researcher surveyed 30 respondents through three angles, such as service quality, perceived price, and customer loyalty. According to the results of previous studies, almost all customers are not satisfied with this indicator. So, this research will focus on: The Effect of Service Quality and Price Perception on Customer Loyalty with Customer Satisfaction as a Mediation Variable. It also considers a significantly greater aspect of dissatisfaction. 


\section{Research Methods}

The research hypothesis testing adopted the Structural Equation Model-Partial Least Square (SEM-PLS) technique using SmartPLS.

\section{Result and Discussion}

Service quality: service quality is a common attribute of a good or service and is identified by its ability to meet various defined and protected needs. So, there are three main themes in determining service quality:

1. For buyers, service quality is more difficult to measure than product quality.

2. Service quality is the result of a comparison between the expectations and the performance achieved by consumers.

3. Service evaluation includes not only service results but also the delivery process.

Quality has quite several parameters and is very dependent on the individual, the definition of quality varies from person to person. Many quality experts try to define quality based on every point of view they see. Some of their definitions are:

1. Quality is the needs and expectations of consumers.

2. Quality is zero defects, integrity, and conformance to requirements.

3. Quality according to specifications.

These three perceptions of quality are at the core of the Total Quality Management (TQM) guideline, which is a central issue. Some experts classify service quality as a unique situation involving service items, individuals, technology, and nature, with the aim of satisfying the desires of the buyers themselves. This explanation emphasizes that quality also focuses on consideration of human quality, process quality, and environmental quality and does not only focus on the final product point, product, or service. Therefore, it requires human support and quality processes to produce quality products or services.

The implementation of service quality for service companies can be used as a competitive advantage as expressed by several experts, namely another important factor in improving service quality is that superior quality is proven to be a competitive strategy in competitive advantage. Companies use services to be different, companies use services to increase productivity, companies use services to gain customer loyalty. Companies use services to spread advertisements by sharing positive word of mouth, companies use services to seek the same protection from price competition.

From this definition, it can be concluded that service quality is the main key in achieving success. The quality of services or goods depends on the ability of producers to meet buyers' expectations. Consumers who are satisfied then indirectly instill loyalty, generate a sense of wanting to recommend word of mouth, and will improve the company's image in the eyes of other consumers. Thus, the focus of company attention is the quality of services provided by the company.

Price perception: When a buyer evaluates the price of a product, the buyer is strongly influenced by consumer behavior. Experts argue that there are 4 main points of view related to social, cultural, personal (age, occupation, economic status) and psychological (belief, motivation, perception) consumer behavior 
Perception has an individual process that consists of selecting, organizing, and translating stimuli and information from a broader perspective. Therefore, the valuation of a product is dependent on individual perceptions based on individual circumstances and circumstances, and may not be highly valued, cheap, or common to everyone. The reality of estimating the price of a product depends on the consumer not only on the nominal price in absolute value, but also on his perception of the price. Basically, consumer perception is related to the perception of price differences and price references.

Some experts understand price perceptions, seen from the suitability of prices and products as well as the suitability of product prices with the financial ability to buy these products. Numerous studies have shown that price perceptions have a large impact on moving objectives. It is no wonder that price competition occurs in every industry. The purpose of price competition is to attract consumers to buy the products offered.

There are similarities in products and services in one industry, so consumers will think twice about what products and services consumers will use. Many experts say that price is an important factor and influence that influences the intention to move from one industry to another. In the transportation industry, tariffs and prices play an important strategic role in determining the marketing strategy, namely the close relationship between price and value, where consumers seek the price offered and the value provided.

Customer satisfaction: Consumer satisfaction is an emotional response to evaluate the experience of consuming a product or service and respond to their experience after using the product and service. Customer satisfaction is a form of customer perception that expectations have been met or exceeded. Customer satisfaction or dissatisfaction is the customer's reaction to the disagreement / dissatisfaction between previous consumer expectations and actual usage experienced by the consumer. Buyer satisfaction is the associative innersing analysis of a purchase when the product choice is equal to or greater than the buyer's expectations. Buyers sometimes experience frustration when results do not meet consumer expectations. According to some experts, customer satisfaction can be divided into two, especially beneficial and psychological. User satisfaction is satisfaction resulting from the performance of the product used, and psychological satisfaction is satisfaction resulting from the intangible nature of the product.

There is intense competition, with more and more producers responding to consumer needs and wants, it should allow all companies to prioritize aspects of customer satisfaction as a priority in the company. This is reflected in the number of companies that are committed to customer satisfaction. Delivering value and customer satisfaction by offering high quality products at competitive affordable prices is the key to winning over the competition.

Service and product quality plays an important role in shaping customer satisfaction, but is also closely related to generating income for businesspeople. The more products and services offered, the more satisfaction the customer will receive. Many experts argue that customer satisfaction is a feeling of happiness and sadness that 
occurs after comparing the overall performance of a product with the expected performance. If the overall performance is not as expected, the buyer will be disappointed by showing disappointment. Conversely, if performance meets expectations, buyers experience happiness. If the overall performance exceeds expectations, the buyer will be very satisfied.

Satisfaction refers to the overall attitude or behavior of the customer towards the services provided, or the emotional response to the difference between what the buyer will receive and what the customer expects. Buyer satisfaction is expressed by the extent to which the performance of a product or service in the business is as expected by the customer. If the performance meets or exceeds expectations, our customers are happy. On the other hand, if the performance is way below expectations, the customer is not always happy.

Some definitions of customer satisfaction can be concluded that the satisfaction obtained by consumers is the result of consumers' usual perceptions of the overall performance that has been produced by the company in response to expectations of the product or service used. The customer's expectation of the product or service received is beyond experience. When there is a failure in the protective joy between desire and hope, it becomes a motive for disappointment.

Customer loyalty: the main goal of the company is to have loyal customers. However, most businesses are not aware of increasing customer loyalty through many steps, from identifying potential customers to supporting customers who support the company. Consumer loyalty is a preference for a brand and over time the consistency of buying that brand.

Many experts claim that consumer loyalty is a key role of a company. Improving financial performance and maintaining the company's survival is one way to maintain customer loyalty. Consumer loyalty is also a basic reason to attract and retain consumers. Building loyal customers is something that does not work right away, but it goes through several stages. This stage includes the stage of finding potential customers to the stage of getting partners. Customer loyalty as a customer commitment to the company over the years or customers making multiple purchases for selected products and services, regardless of the influence of the situation and other company marketing efforts that can cause behavior change.

Consumer loyalty features include: 1. Repeating regular purchases. 2. Buy between service or product lines. 3. Evidence of resistance to rival temptations. 4 . Will not be forced to sell to others. Becoming a loyal client takes many steps. Gradually, loyal customers appeared. This process is carried out over a period, with love and care at every stage of development. By identifying each stage and meeting specific needs, companies increase the chances of calling on loyal buyers, or customer loyalty.

Loyalty is a combination of psychological and consumer behavior, as well as loyalty to certain products or services provided by the company. Regardless of how behavior changes depending on the status and impact of marketing activities, Royalties is committed to preserving details for the future by continuing to repurchase or resubscribe to certain products or services. 
Based on the many definitions of customer loyalty, it can be concluded that customer loyalty is a customer who is loyal to buy and become a customer at a particular company, and creates a positive attitude towards certain company products, has a commitment as a customer to a company that you want to continue to use in the future. And the emergence of an attitude of recommending others to buy.

\section{Conclusion}

The results of this study indicate that service quality does not have a significant effect on customer satisfaction because consumers feel the services provided by Indomaret employees are mandatory. In addition, there is a perception of price which has a significant influence or influence on customer satisfaction. The perception that customers will bear on prices can trigger customers to feel satisfied with Indomaret because in Indomaret there are many promising promotions and discounts so that customers are satisfied when shopping at Indomaret. Customer satisfaction also affects customer loyalty. Customer loyalty has important values for a company, customer loyalty will be able to grow if customers are satisfied with what Indomaret has to offer.

\section{References}

[1] Henseler, J., Ringle, C. M., \& Sinkovics, R. R. (2009). The use of partial least squares path modeling in international marketing. Advances in International Marketing, 20(1), 277-319.

[2] Kubberød, E., \& Pettersen, I. B. (2017). Exploring situated ambiguity in students' entrepreneurial learning. Education and Training, 59(3), 265-279.

[3] Wibowo, J., \& Santoso, R. (2020). PEMBUATAN DIGITAL MARKETING DAN MARKETING CHANNEL UNTUK UKM PJ COLLECTION. JPM17: Jurnal Pengabdian Masyarakat, 5(01), 82-91.

[4] Potishuk, V., \& Kratzer, J. (2017). Factors affecting entrepreneurial intentions and entrepreneurial attitude in higher education. Journal of Entrepreneurship Education, 20(1), 25-44.

[5] Smith, S., Hamilton, M., \& Fabian, K. (2019). Entrepreneurial drivers, barriers and enablers of computing students: Gendered perspectives from an Australian and UK university. Studies in Higher Education, 28, 1-14.

[6] Santoso, R., Candraningrat, C., \& Binawati, L. (2017). Elemen Kecerdasan Wirausaha Untuk Meningkatkan Kinerja Industri Kecil dan Menengah (IKM) di Surabaya.

[7] Kwabena Nkansah Simpeh. (2011). Entrepreneurship theories and empirical research: A summary review of the literature. European Journal of Business and Management, 3(6), 1-8.

[8] Santoso, R., Erstiawan, M. S., \& Kusworo, A. Y. (2020). Inovasi Produk, Kreatifitas Iklan Dan Brand Trust Mendorong Keputusan Pembelian. Jurnal Nusantara Aplikasi Manajemen Bisnis, 5(2), 133-145.

[9] Marques, C. S., Ferreira, J. J., Gomes, D. N., \& Rodrigues, R. G. (2012). Entrepreneurship education: How psychological, demographic and behavioural factors predict the entrepreneurial intention. Education \& Training, 54(8/9), 657672. 
[10] Fianto, A. Y. A. (2020). Satifaction as intervening for the antecedents of intention to revisit: Marine tourism context in East Java. Relasi: Jurnal Ekonomi, 16(1), 179207.

[11] Obschonka, M., Hahn, E., \& Bajwa, N. (2018). Personal agency in newly arrived refugees: The role of personality, entrepreneurial cognitions and intentions, and career adaptability. Journal of Vocational Behavior, 105, 173-184.

[12] Santoso, R., Shinta, R., \& Fianto, A. Y. A. (2019). Pengaruh Bauran Pemasaran Jasa terhadap Keputusan Berkunjung ke Wisata Bahari Jawa Timur. Jurnal MEBIS (Manajemen dan Bisnis), 4(2), 73- 86. 